\title{
THE ROLE OF BRAND LOVE MEDIATES THE INFLUENCE OF BRAND EXPERIENCE AND SELF EXPRESSIVE BRAND ON BRAND LOYALTY: A CASE STUDY ON STARBUCKS CONSUMERS IN DENPASAR
}

\author{
Widiasuari Riyasa Ida Ayu Putri*, Sukaatmadja I Putu Gde \\ Faculty of Economics and Business, University of Udayana, Bali, Indonesia \\ *E-mail: idaayuputriwidiasuari@yahoo.com
}

\begin{abstract}
The business world has developed quite rapidly, namely coffee shops by producing products so that they are able to meet the needs and tastes of consumers with good brand quality. One coffee shop brand that is superior to the others today is Starbucks. The Starbucks brand is able to compete with competition between brands and remain in the first position seen from the consumer's brand experience and self-expressive brand. The purpose of this study was to examine and explain the role of brand love in mediating the influence of brand experience and self-expressive brand on the loyalty of Starbucks consumers. The research subjects were Starbucks consumers with a sample of 120 people. The sample was determined using a non-probability sampling method, namely purposive sampling. Data were analyzed using SEM-PLS technique. The results of this study indicate that brand experience has a positive and insignificant effect on brand loyalty, self-expressive brand has a positive and significant effect on brand loyalty, brand experience has a positive and significant effect on brand love, self-expressive brand has a positive and significant effect on brand love, and brand love is able to mediate the effect of brand experience and brand self-expression on brand loyalty. The theoretical implication that can be given from the research findings is that it can provide an empirical contribution to the relationship between the variables of brand experience, self-expressive brand, brand love and brand loyalty for the development of marketing management science. The practical implications that can be given from the research findings show that among the three variables that affect brand loyalty, the brand love variable has the highest path coefficient, which can be a reference for Starbucks management in making strategies to increase brand loyalty to Starbucks consumers by increasing the brand love.
\end{abstract}

\section{KEY WORDS}

Brand Experience, self-expressive brand, brand love, brand loyalty, Starbucks

The business world has developed quite rapidly so that companies are required to produce products or services that are able to meet the needs and tastes of consumers with good brand quality in the midst of a competitive market (Nurhayati, 2020). With the role of the brand, it is necessary for the company to create a brand that is valuable for the product so that it can compete. Companies will be faced with increasingly fierce business competition. The intense competition makes every company or individual conducting business required to carry out its business strategy to maintain and increase customer loyalty (Hakim and Purwoko, 2019). This situation occurs in competition of coffee shops in Indonesia, because Indonesia is one of the largest coffee-producing country in the world, is ranked fourth with 11.185 million (www.ico.org). Coffee is recorded as the third most consumed beverage worldwide, including in Indonesia, after water and tea, so that it becomes a business opportunity in setting up coffee shops in Indonesia.

The business competition that occurs in Indonesia is very tight, one of which is coffee shops. One of the famous coffee shop brands in Indonesia is Starbucks. Starbucks has been in the Top Brand Award from 2017 to 2020, which shows that Starbucks is ranked first for four consecutive years, followed by international and local products.

Revenue at Starbucks coffee shops in 2017 - 2020 has decreased, seen from the average total revenue of 2.13 percent. The 2020 decline was due to the outbreak of the 
Covid-19 pandemic (Potensibisnis.com). The Starbucks coffee shop in Denpasar, in the face of the new normal, will reduce the seating capacity in the dine-in area, thus causing a decrease in revenue in 2020 (kompas.com) however, consumers remain loyal to Starbucks by buying Starbucks products through delivery or consumers who stay enthusiastic about visiting Starbucks by using health protocols following government regulations.

Tight competition and the existence of Covid-19, it is important to create brand loyalty to consumers to ensure that consumers are loyal to the brand (Agnes, 2020). Brand loyalty can be a competitive advantage for companies in the market because it can be assessed in terms of behavior and attitudes (Madeline et al., 2019). A strong brand can create brand loyalty in the long run so that consumers are able to see the brand as a good product or service (Pertiwi et al., 2017). The company realizes that brand loyalty is a company advantage because it is an important asset for the company (Juliana, 2019). To increase brand loyalty, it needs to be based on a satisfying customer experience with a brand which is a very good initial capital in increasing brand loyalty (Thomas, 2020). Consumers will evaluate the perceived quality of a product from the buying experience, as a result of which brand loyalty increases (Eliasari and Sukaatmadja, 2017).

Brand experience is the sensation, feeling, cognition, and consumer responses generated by the brand, related to the stimuli generated by the brand design, brand identity, marketing communications, people and the environment the brand is marketed to (Brakus et al, 2009). Brand experience has a big influence on customer satisfaction because customers do not only expect a superior function of the product purchased but also the experience gained when buying or consuming the product (Nyohardi, 2016). A satisfying customer experience with a brand is a very good initial capital in increasing brand loyalty. A satisfying customer experience with a brand is a very good initial capital in increasing brand loyalty. Apart from brand experience, there is still a determinant of brand loyalty, namely selfexpressive brands.

Self-expressive brand is the customer's perception of the extent of the brand's influence in increasing social-self or inner-self (Ahuvia, 2006: 82). Brands can express themselves so that they lead to brand loyalty (Ramadhina, 2016). Self-expressive brand research has a positive and significant effect on brand loyalty (Lee and Workman, 2015; Ruane and Wallace, 2016; Ramadhina, 2016; and Kostritsa et al., 2020). However, this study is not supported by research which states that self-expressive brands have no significant effect on brand loyalty (Leckie et al., 2016). There is an inconsistency in the results of research between brand experience and self-expressive brand on brand loyalty, so brand love is used as a mediating variable.

Brand love is an enthusiastic emotional bond accompanied by a satisfying consumption experience. Consumers with a more hedonistic tendency may experience the brand love phenomenon more often (Gao, 2016). Consumers who have feelings of love begin to have a relationship and emotionality with the brand (Batra et al., 2016). A positive experience with the use of a brand encourages consumers to love a brand more (Ferreira et al., 2019). Brand experience is a dominating factor because in addition to caring about how a brand can carry out its functions, consumers enjoy moments or experiences interacting with the brand to stimulate emotions and feelings of love for the brand (Silvana et al., 2018). This is supported by the fact that brand experience has a positive and significant effect on brand love (Bambang et al., 2017; Bıçakcıoğlu et al., 2018; Madeline et al., 2019; and Thomas, 2020).

A beloved brand is part of the consumer's self-expression. Consumers by using certain brands and showing love for these brands can express themselves to others (Fernandus, 2017). Brands that can encourage consumers to express themselves, will make the brand loved by consumers. This research is supported by the fact that self-expressive brands have a positive and significant effect on brand love (Algharabat, 2017; Fernandus, 2017; and Olivia, 2019)

Brand love relationships can last a long time, so it means that a brand that is loved by consumers is considered irreplaceable and is increasingly loyal to the brand. Brand love also leads to positive perceptions of brands (Albert and Merunka, 2013), the higher the brand love 
shown by consumers will have a direct influence on brand loyalty. This is supported by research that brand love has a positive and significant effect on brand loyalty (Sari and Sudarti, 2016; Lestari et al., 2018; Bairrada et al., 2019; and Madeline et al., 2019). Based on the background, the following hypothesis is formulated:

- $\mathrm{H} 1$ : the effect of brand experience on brand loyalty;

- H2: the effect of self-expressive brand on brand loyalty;

- H3: the effect of brand experience on brand love;

- H4: the influence of self-expressive brands on brand love;

- H5: the effect of brand love on brand loyalty;

- H6: the role of brand love mediates the effect of brand experience on brand loyalty;

- $\mathrm{H} 7$ : the role of brand love mediates the influence of self-expressive brands on brand loyalty.

\section{METHODS OF RESEARCH}

This research uses quantitative data which is analyzed associatively. In this study, nonprobability sampling was used to collect samples with purposive sampling method, namely the sampling technique with certain considerations. This research was conducted in Denpasar because the income of residents in Denpasar City is number one highest in Bali (BPS, 2020) and productive population aged 15 years and over of 523,524 people, which is the number one highest in Bali (BPS, 2020). The population in this study was all consumers in Denpasar who had visited and purchased Starbucks products in the last six months. This study uses 15 indicators so that the sample required is 120 respondents. The data analysis method used was descriptive statistical analysis and inferential statistical analysis which was analyzed with the Smart-PLS software.

\section{RESULTS AND DISCUSSION}

Based on the results of the characteristics of the respondents in this study, the dominant Starbucks consumers were female than male, namely 80 people or 66.7 percent. This means that female Starbucks consumers visit and consumes Starbucks more, which means that female respondents enjoy doing activities such as socializing with friends and colleagues and supporting facilities that make work easier for women. Starbucks consumers aged $22-26$ years. is the most among the others, namely 91 people or 75.9 percent. This phenomenon states that Starbucks consumers aged 23-26 visits and consume the most Starbucks. Then, the last education of the most dominant respondents was $\mathrm{S} 1$ with 101 people or 84.2 percent. This phenomenon states that Starbucks consumers who have a bachelor's degree consume the most and visit Starbucks. Based on the work, the most dominant Starbucks consumers are students or university students as many as 51 people or 42.5 percent. This phenomenon states that Starbucks consumers who are students or college students mostly visit and consume Starbucks. Based on location of respondent, the most respondents came from South Denpasar with 42 people or 35 percent, this is because the locations of most Starbucks coffee shops are in South Denpasar.

Table 1 - Result of Direct Effect Test

\begin{tabular}{lllll}
\hline & Path Coefficient & t statistics & $P$ Values & Significance \\
\hline Brand Experience $\left(\mathrm{X}_{1}\right)->$ Brand Loyalty $\left(\mathrm{Y}_{2}\right)$ & 0,024 & 0,397 & 0,692 & Not Significant \\
\hline Self-Expressive Brand $\left(\mathrm{X}_{2}\right)->$ Brand Loyalty $\left(\mathrm{Y}_{2}\right)$ & 0,636 & 2,994 & 0,003 & Significant \\
\hline Brand Experience $\left(\mathrm{X}_{1}\right)->$ Brand Love $\left(\mathrm{Y}_{1}\right)$ & 0,168 & 2,466 & 0,014 & Significant \\
\hline Self-Expressive Brand $\left(\mathrm{X}_{2}\right)->$ Brand Love $\left(\mathrm{Y}_{1}\right)$ & 0,636 & 10,285 & 0.000 & Significant \\
\hline Brand Love $\left(\mathrm{Y}_{1}\right)->$ Brand Loyalty $\left(\mathrm{Y}_{2}\right)$ & 0,622 & 8,170 & 0.000 & Significant \\
\hline
\end{tabular}

Source: Primary data processed, 2021. 


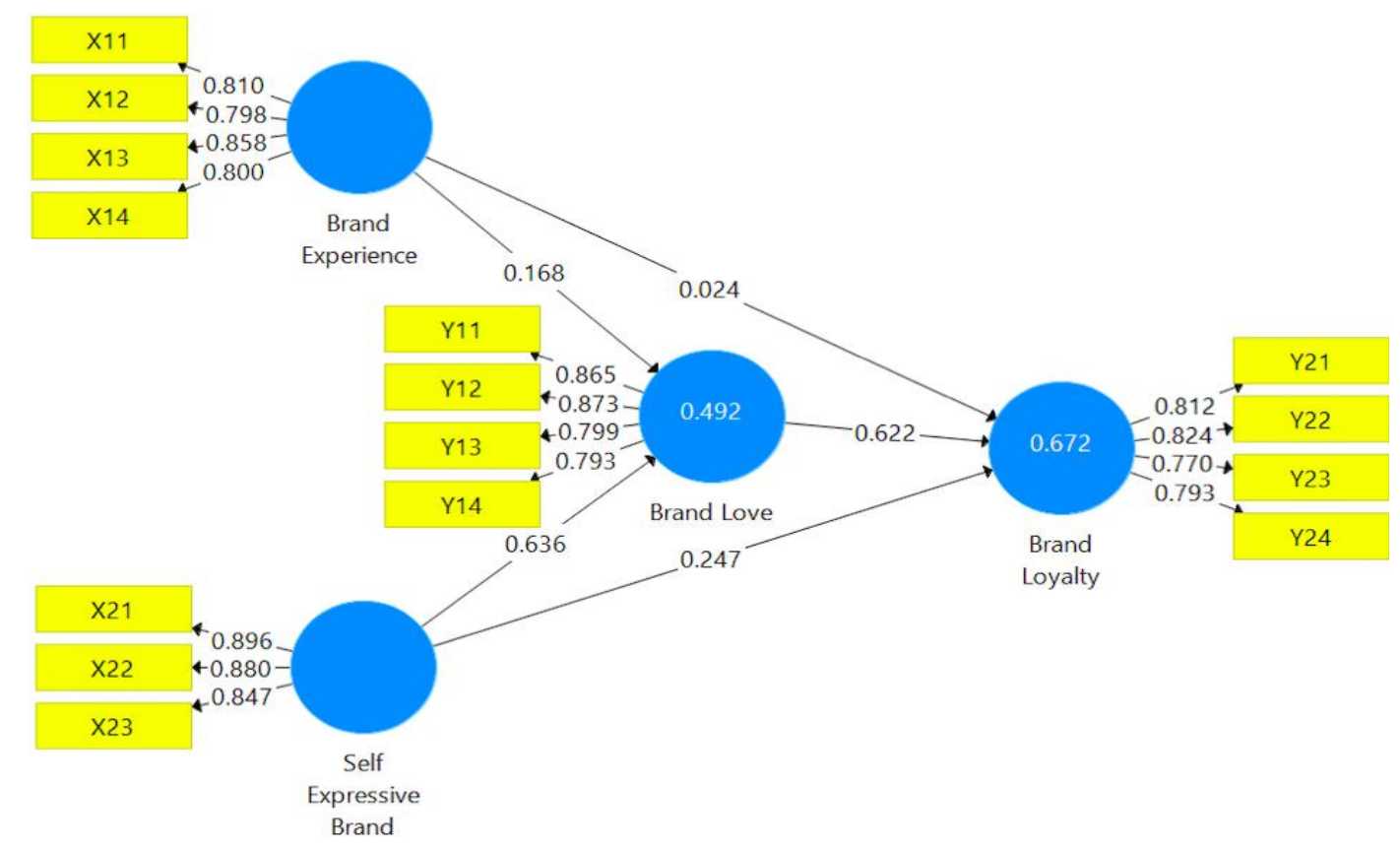

Figure 1 - Structural Model

Table 2 - Recapitulation of Test Results for Mediation Variables

\begin{tabular}{|c|c|c|c|c|c|}
\hline \multirow{2}{*}{ Variable Relationships } & \multicolumn{4}{|l|}{ Effect } & \multirow{2}{*}{ Information } \\
\hline & (A) & (B) & (C) & (D) & \\
\hline $\begin{array}{l}\text { Brand Experience (X1) }->\text { Brand Love (Y1) } \rightarrow> \\
\text { Brand Loyalty }(\mathrm{Y} 2)\end{array}$ & $\begin{array}{l}0,105 \\
\text { (Sig.) }\end{array}$ & $\begin{array}{l}0,024 \\
\text { (Non- } \\
\text { Sig.) }\end{array}$ & $\begin{array}{l}0,168 \\
\text { (Sig.) }\end{array}$ & $\begin{array}{l}0,622 \\
\text { (Sig.) }\end{array}$ & $\begin{array}{l}\text { Full } \\
\text { Mediation }\end{array}$ \\
\hline $\begin{array}{l}\text { Self-Expressive Brand (X2) -> Brand Love (Y1) -> } \\
\text { Brand Loyalty }(\mathrm{Y} 2)\end{array}$ & $\begin{array}{l}0,396 \\
\text { (Sig.) }\end{array}$ & $\begin{array}{l}0,247 \\
\text { (Sig.) }\end{array}$ & $\begin{array}{l}0,636 \\
(\text { Sig.) }\end{array}$ & $\begin{array}{l}0,622 \\
\text { (Sig.) }\end{array}$ & $\begin{array}{l}\text { Partial } \\
\text { Mediation }\end{array}$ \\
\hline
\end{tabular}

Source: Data processed results, 2021.

Information: significance (Sig.) $=T$-statistic $>1.96$ at a $=5 \%$.

(a) The indirect effect of exogenous variables ( $X 1$ or $X 2)$ on endogenous variables ( $Y 1)$.

(b) The direct effect of exogenous variables ( $X 1$ or $X 2$ ) on endogenous variables ( $Y 2$ ).

(c) The direct effect of exogenous variables ( $X 1$ or $X 2)$ on endogenous variables ( $Y 1)$.

(d) Direct effect of endogenous variables (Y1) on endogenous variables (Y2).

The results of the analysis show that brand experience has a positive and insignificant effect on brand loyalty among Starbucks consumers in Denpasar. This means that more experience visiting and consuming Starbucks will increase brand loyalty is not proven. This means that experience is not able to increase Starbucks brand loyalty in Denpasar City. The experience referred to in this study is the experience of visiting and consuming Starbucks. Based on the measurement results obtained, the experience in shopping convenience is the strongest dating $r$, reflecting the experience variable and from the empirical facts it has also been implemented well (mean value of 4.63). The brand loyalty variable is reflected in the strong desire to repurchase the brand with the highest outer loading of 0.672 , but the respondents' assessment of the only Starbucks brand that consumers will buy is still low (with an average of 2.94). The low level of consumer awareness of the Starbucks brand is due to the emergence of many coffee shop competitors that make consumers try to visit and buy coffee to other coffee shops as well as some barista services that are less than optimal. The results of this study also state that they are in line with and in accordance with the results of previous research by Mergie and Ivan (2014) which state that the loyalty of a consumer depends on the product or service itself, so in research consumers will not be immediately loyal to the brand. The results of these studies are also supported by Pranadata et al. (2017) and Rahmat and Marso (2020) who state that brand experience has a positive and insignificant effect on brand loyalty. 
The analysis result shows that self-expressive brand has a positive and significant effect on brand loyalty. This means that the better the self-expressive brand of Starbucks consumers, the higher the brand loyalty. These results indicate that the values contained in the self-expressive brand can increase brand loyalty to Starbucks consumers. Selfexpressive brand as measured by dating $r$ : describes personality, enhances self-image, and improves the perspective of others. This finding may imply that the better the consumer's personality, the higher the desire to come to Starbucks. The results of this study are consistent with the results of research by Lee and Workman (2015) who found that consumer loyalty to brands that express themselves can play an important role in strengthening their personal and social identities. These results are also in accordance with research by (Ruanne and Wallace, 2016; Ramadhina, 2017; Kosritsa et al., 2020) which states that selfexpressive brands have a positive and significant effect on brand loyalty.

Table 3 - Direct Effect, Indirect Effect, Total Variable Effect, and Calculation of VAF

\begin{tabular}{|c|c|c|}
\hline \multirow{2}{*}{ Variable } & \multicolumn{2}{|l|}{ Direct Effect } \\
\hline & Correlation coefficient & $t$-Statistics \\
\hline Brand Experience $\left(\mathrm{X}_{1}\right)->$ Brand Loyalty $\left(\mathrm{Y}_{2}\right)$ & 0,024 & 0,397 \\
\hline Self-Expressive Brand $\left(\mathrm{X}_{2}\right)$-> Brand Loyalty $\left(\mathrm{Y}_{2}\right)$ & 0,247 & 2,994 \\
\hline Brand Experience $\left(\mathrm{X}_{1}\right) \rightarrow$ Brand Love $\left(\mathrm{Y}_{1}\right)$ & 0,168 & 2,466 \\
\hline Self-Expressive Brand $\left(\mathrm{X}_{2}\right)->$ Brand Love $\left(\mathrm{Y}_{1}\right)$ & 0,636 & 10,285 \\
\hline Brand Love $\left(\mathrm{Y}_{1}\right)->$ Brand Loyalty $\left(\mathrm{Y}_{2}\right)$ & 0,622 & 8,170 \\
\hline \multirow{2}{*}{ Variable } & \multicolumn{2}{|l|}{ Indirect Effect } \\
\hline & Correlation coefficient & $t$-Statistics \\
\hline \multirow{2}{*}{$\begin{array}{l}\text { Brand Experience }\left(\mathrm{X}_{1}\right)->\text { Brand Love }\left(\mathrm{Y}_{1}\right)->\text { Brand Loyalty }\left(\mathrm{Y}_{2}\right) \\
\text { Self-Expressive Brand }\left(\mathrm{X}_{2}\right)->\text { Brand Love }\left(\mathrm{Y}_{1}\right)->\text { Brand Loyalty }\left(\mathrm{Y}_{2}\right)\end{array}$} & 0,105 & 2,331 \\
\hline & 0,396 & 6,119 \\
\hline \multirow{2}{*}{ Variable } & \multicolumn{2}{|l|}{ Total Effect } \\
\hline & Correlation coefficient & t-Statistics \\
\hline Brand Experience $\left(\mathrm{X}_{1}\right)->$ Brand Loyalty $\left(\mathrm{Y}_{2}\right)$ & 0,129 & 2,119 \\
\hline Self-Expressive Brand $\left(\mathrm{X}_{2}\right)$-> Brand Loyalty $\left(\mathrm{Y}_{2}\right)$ & 0,643 & 12,466 \\
\hline Brand Experience $\left(\mathrm{X}_{1}\right) \rightarrow$ Brand Love $\left(\mathrm{Y}_{1}\right)$ & 0,168 & 2,206 \\
\hline Self-Expressive Brand $\left(\mathrm{X}_{2}\right)->$ Brand Love $\left(\mathrm{Y}_{1}\right)$ & 0,636 & 10,315 \\
\hline Brand Love $\left(\mathrm{Y}_{1}\right)->$ Brand Loyalty $\left(\mathrm{Y}_{2}\right)$ & 0,622 & 9,920 \\
\hline VAF -> Indirect Effect / Total Effect $(0,105 / 0,129)$ & 0,813 & \\
\hline VAF -> Indirect Effect / Total Effect $(0,396 / 0,643)$ & 0,615 & \\
\hline
\end{tabular}

Source: Primary data processed, 2021.

The results of the analysis show that brand experience has a positive and significant effect on brand love. This means that the better the brand experience of Starbucks consumers, the higher the love for the brand. These results indicate that the values contained in the brand experience can increase brand love for Starbucks consumers. Brand experience as measured by dating $r$ : company layout, comfort, friendly attitude and the company routinely interacts with customers. This finding can be interpreted that the better the consumer experience when it is easy to find Starbucks locations, provide good service, and routinely provide information about Starbucks promos to consumers, resulting in feelings of love from consumers for the Starbucks brand. The results of this study are in accordance with the results of research by Huang (2017) who found that if a company is able to give a good impression, it can create a good experience in the minds of consumers that can create a sense of the brand. These results are also consistent with research by (Bambang et al. 2017; Bıçakcıoğlu et al 2018; Yang et al., 2018; and Madeline et al., 2019) which states that brand experience has a positive and significant effect on brand love.

The results of the analysis show that the self-expressive brand has a positive and significant effect on brand love. This means that the better the self-expressive brand of Starbucks consumers, the higher the love for the brand. These results indicate that the values contained in the self-expressive brand can increase brand loyalty to Starbucks consumers. Self-expressive brand as measured by dating $r$ : describes personality, enhances self-image, and improves the perspective of others. This finding can be interpreted that the better the consumer's personality so that it can increase a good consumer image in the 
minds of other consumers, it can lead to feelings of love from consumers for the Starbucks brand. The results of this study are in accordance with the results of research by Olivia (2019) which found that if stores increase brand love, it is very important to pay attention to the extent to which the brand's expression (self-expressive brand) has. Thus it can be said, if a brand must play a role in shaping consumer identity so that it can increase consumer love for the brand. These results are also in accordance with research by (Algharabat, 2017; Fernandus, 2017; and Kostritsa et al., 2020) which states that self-expressive brands have a positive and significant effect on brand love.

The results of the analysis show that brand love has a positive and significant effect on brand loyalty. This means that the higher the brand love of Starbucks consumers, the higher the loyalty to the brand. These results indicate that the values contained in brand love can increase brand loyalty to Starbucks consumers. Brand love is measured based on indicators: consumers love brands, strong emotional relationships, consumers are very attached to the brand and have a long-term relationship with a brand. This finding may imply that the higher the consumer's love for the brand, the higher the desire to come to Starbucks. The results of this study are in accordance with the results of research by Bambang et al. (2017) who found that the higher brand love shown by consumers will have a direct effect on brand loyalty of coffee cafes. These results are also in accordance with research by (Sari and Sudarti, 2016; Lestari et al., 2018; Bairrada et al., 2019; et al., 2019; and Kostritsa et al., 2020) which states that brand love has a positive and significant effect towards brand loyalty.

The role of brand love mediates the effect of brand experience on brand loyalty. The results of the analysis show that brand love is able to mediate the effect of brand experience on brand loyalty. Brand love in this study is a full mediation (full mediation, which means that consumer experience in consuming Starbucks has not been able to increase brand loyalty to consumers, but with the presence of brand love generated by consumers, it can lead to brand loyalty to Starbucks consumers. This means that the better the brand experience is felt, it can create brand love so that it can increase brand loyalty to consumers. The results of this study support the previous study by Huang (2017) who found that a good experience in the minds of consumers can create a sense of the brand. Research results (Bambang et al., 2017; Yang et al., 2018); and Madeline et al., 2019) state that brand experience has a positive and significant effect on brand love. Research results on the effect of brand love on brand loyalty are also supported by research (Sari and Sudarti, 2016; Bambang et al., 2017; Lestari et al., 2018; Bairrada et al., 2019; and Kostritsa et al., 2020). The results of this study also support the research conducted by Bıçakcıoğlu et al. (2018) and (Madeline et al., 2019) found that brand love mediates the effect of brand experience on brand loyalty.

The role of brand love mediates the influence of self-expressive brand on brand loyalty. The results of the analysis show that brand love is able to mediate the effect of brand selfexpression on brand loyalty. Brand love in this study is a partial mediation. Based on these results it can be interpreted that the better the self-expressive brand in consumers can create brand love to increase brand loyalty to consumers. The results of this study support the previous study by Olivia (2019) which found that brands must play a role in shaping consumer identity so that they can increase consumer love for the brand. Research results (Fernandus, 2017); and (Kostritsa et al, 2020) state that self-expressive brands have a positive and significant effect on brand love. Research results on the effect of brand love on brand loyalty are also supported by research (Sari and Sudarti, 2016; Bambang et al., 2017; Lestari et al., 2018; Bairrada et al., 2019; and Kostritsa et al., 2020). The results of this study also support research conducted by (Algharabat, 2017) which found that brand love mediates the effect of self-expressive brands on brand loyalty.

The scope of the research is limited to the city of Denpasar, so the results of this study cannot be generalized to consumers in a wider area. This research is limited to examining the variables of brand experience, self-expressive brand, brand love and brand loyalty, thus it cannot be more researched. In-depth dating of factors outside these variables, and this study uses a cross-sectional time design or at a certain point in time; but on the other hand, this study observes the dynamics of conditions that change every period, therefore this research is important to examine the future. 


\section{CONCLUSION}

Based on the results of the research analysis, the conclusion of this study is that brand experience has a positive and insignificant effect on Starbucks consumer brand loyalty. This means that if the consumer's brand experience increases, the consumer's brand loyalty in visiting and consuming Starbucks does not necessarily increase, Self-expressive brands have a positive and significant effect on Starbucks consumer brand loyalty. This means that if the self-expressive brand increases, the consumer's brand loyalty in visiting and consuming Starbucks will also increase. Brand experience has a positive and significant effect on the brand love of Starbucks consumers. This means that if the brand experience increases, the brand love of consumers in visiting and consuming Starbucks will increase as well. Self-expressive brands have a positive and significant effect on the brand love of Starbucks consumers. This means that if the self-expressive brand increases, the brand love of consumers in visiting and consuming Starbucks will also increase. Brand love has a positive and significant effect on Starbucks consumer brand loyalty. This means that if brand love increases, consumer brand loyalty in visiting and consuming Starbucks will also increase. Brand love is able to mediate the effect of brand experience on Starbucks consumer brand loyalty. This shows that the brand experience of Starbucks consumers has not been able to have a significant impact on consumer brand loyalty, but if it is mediated by brand love, the brand experience felt by consumers can increase Starbucks brand loyalty, and brand love is able to mediate the influence of self-expressive brands. to Starbucks consumer brand loyalty. This shows that the self-expressive brand of Starbucks consumers will have a significant impact on user brand loyalty if it is mediated by brand love, which means that the loyalty of Starbucks consumers is very dependent on the level of consumer brand self-expression and also the level of brand love.

Based on the results of the research analysis, to increase Starbucks consumer brand loyalty, it is recommended that Starbucks management provide a good brand experience by providing maximum service such as providing product information to consumers giving an alarm to consumers so that there is no mistake in taking drinks to consumers, to improve self-expressive brand, so the management also needs to hold promotions such as discounts regarding consumers who upload photos or videos on social media for each individual consumer, to be able to improve the brand experience of Starbucks consumers, it is advisable for Starbucks management to create brand experiences such as friendliness and politeness of Starbucks baristas to get maximum service and to be able to increase the selfexpressive brand of Starbucks consumers, Starbucks management should create a selfexpressive brand by doing promotions or providing benefits such as discounts when customers uploading their photo on their social media.

\section{REFERENCES}

1. Agnes, N. 2020. Brand Awareness, Brand Image and Brand loyalty Sebagai Prediktor Brand Equity Adidas. Jurnal Manajerial and Kewirausahaan, 2(20):240-50.

2. Ahuvia, A.C. 2006. Beyond The Extended Self: Loved Objects And Consumers' Identity Narratives. Journal of Consumer Research, 32(1) :171-84.

3. Albert, and Merunka. 2013. The Role of Brand love In Consumer-Brand Relationships. Journal of Consumer Marketing, 30(3):258-66.

4. Algharabat, R. S. 2017. Kybernetes Article Information :Linking Social Media Marketing Activities With Brand love The Mediating Role Of Self-Expressive Brands." Journal Kybernates (Emeral Insight), 46(10):1801-19.

5. Bairrada, Cristela, M., Arnaldo, C., and Viktoriya, L. 2019. The Impact Of Brand Personality On Consumer Behavior: The Role of Brand love. Journal of Fashion Marketing And Management, 23(1):30-47

6. Bambang, A., Rahman, L., and Nurdasila, D. 2017. Pengaruh Brand Image, Brand Personality, Brand Experience Terhadap Brand love Dampaknya Pada Brand loyalty Gayo Aceh Coffee Pt Oro Kopi Gaya Kabupaten Aceh Tengah. Jurnal Perspektif 
Manajemen and Perbankan, 8(3):158-84.

7. Batra, R., Ahuvia, A., and Bagozzi, R. P. 2016. Brand love: Conctruct Valididty, Managerial Utility, And New Conceptual Insight. Journal of Marketing, 76(2): 1-16.

8. Bıçakcıoğlu et al, 2018. Antecedents And Outcomes of Brand love: The Mediating Role Of Brand loyalty. Journal Of Marketing Communications, 24(8): 863-77.

9. Brakus, J. J., Bernd, H. S., and Lia, Z. 2009. Brand experience: What Is It? How Is It Measured? Does It Affect Loyalty?. Journal Of Marketing, 73(3): 52-68.

10. Eliasari, P.R.A., and Sukaatmadja, I.P.G. 2017. Pengaruh Brand Awareness Terhadap Purchase Intention Dimediasi Oleh Perceived Quality and Brand Loyalty. E-Jurnal Manajemen Unud, 6 (12) : 6620-6650.

11. Fernandus, E. 2017. Pengaruh Self-Expressive Brand, Brand Tribe, Brand love, Terhadap Word Of Mouth. Jurnal Manajemen Bisnis and Kewirausahaan, 1(2):132-47.

12. Ferreira, P., Paula, R., Pedro, R. 2019. Brand Love as Mediator of the Brand ExperienceSatisfaction-Loyalty Relationship in a Retail Fashion Brand. Journal Management and Marketing Sciendo, 14 (3): 278-291

13. Gao, X. 2016. Relationship Between Community Attachment, Brand Identity And Brand love: Based On The Experience Of Consumer'S Emotional Value Perspective. Euporian Journal of Business and Management, 8(35): 169-75.

14. Hakim, B.N. et al, 2019. Strategi Pengembangan Produk Terhadap Loyalitas Pelanggan Melalui Ekuitas Merek and Citra Merek. Jurnal Ekobisman, 3 (3): 261-278.

15. Kostritsa, M., Liebl, H., Beinhauer, R., and Turčínková, J. 2020. Consumer Brand love For Luxury Brands In India. Acta Universitatis Agriculturae Et Silviculturae Mendelianae Brunensis, 68(1): 189-197.

16. Leckie, C., Munyaradzi, W. N., and Lester, W. J. 2016. Antecedents Of Consumer Brand Engagement And Brand loyalty. Journal of Marketing Management. 32(5-6): 558-78.

17. Lee, S. H., and Workman, J E. 2015. Determinants Of Brand loyalty: Self-Construal, SelfExpressive Brands, And Brand Attachment. International Journal of Fashion Design, Technology And Education, 8(1): 12-20.

18. Lestari, S., A. and Fauzi, Sadalia, I. 2018. Analysis of Impact of Consumer Emotional Aspects On Brand loyalty In Gold Installment Product. Journal Kne Social Sciences, 3(10): 930-43.

19. Madeline., Sharon., and Sabrina, O. S. 2019. The Impacts of Brand experiences On Brand love, Brand Trust, And Brand loyalty: An Empirical Study. Jurnal Bisnis and Manajemen, 20(2): 91-107.

20. Nurhayati, S. 2020. Pengaruh Brand Trust, Brand Experience and Kepuasan Pelanggan Terhadap Loyalitas Pelanggan. Jurnal Bisnis, Manajemen and Akuntansi, 7 (2) : 36-46.

21. Nyohardi, P. 2016. Pengaruh Brand experience Terhadap Brand loyalty Melalui Brand Satisfaction and Brand Attitude. Jurnal Bisnis and Manajemen, 52(11): 159-85.

22. Olivia, M. H. 2019. Pengaruh Faktor-Faktor Hedonic Product and Self-Expressive Brand Terhadap Willingness To Pay A Premium Dengan Brand love Pada Toko Ritel Zara. Jurnal Strategi Pemasaran, 6(1): 1-11.

23. Pertiwi et al, 2017. Pengaruh Brand experience Terhadap Brand Satisfaction, Brand Trust and Brand loyalty (Studi Pada Konsumen Make-Up Brand Impor Di Surabaya). Jurnal Manajemen and Kewirausahaan, 5(2): 20-35.

24. Ramadhina, F. A. 2016. The Influence Of Hedonic Product, Self-Expressive Brand, And Satisfaction On Brand love And Brand loyalty: Study Of Starbucks Consumers In Malang. Jurnal IImiah Manajemen, 5(12): 1-15.

25. Ruane, L. et al, 2015. Brand Tribalism and Self expressive brands: Social Influences and Brand Outcomes. Journal of Product and Brand Management, 24(4): 333-348.

26. Sari, P.Y., and Ken, S. 2016. Peningkatan Brand loyalty Melalui Brand Image, Brand love, and Customer Satisfaction (Brand loyalty Through Improved Brand Image, Brand love, And Customer Satisfaction). Fokus Ekonomi Jurnal Ilmiah Ekonomi, 11(1): 1-22.

27. Thomas, W. P. 2020. Brand experience, Perceived Value, Brand Trust Untuk Memprediksi Brand loyalty: Brand love Sebagai Variabel Mediasi. Jurnal Muara IImu Ekonomi and Bisnis, 4 (1): 184-193. 